\title{
HOUSE PRICE APPRECIATION IN OLD AGE: ANALYSIS AND ISSUES FOR THE USE OF REVERSE MORTGAGES AS A RETIREMENT FUNDING STRATEGY IN AUSTRALIA
}

\author{
Rachel Ong \\ Box U1987, Perth WA 6845 \\ $\mathrm{Ph}:+61892662841$ \\ Fax: +61 892663026 \\ Email: r.ong@ @urtin.edu.au
}

School of Economics \& Finance, Curtin Business School, Curtin University of Technology, GPO

\begin{abstract}
This paper investigates whether the houses of Australian elderly home owners appreciate at below the market rate and examines the issues this may raise for the use of reverse mortgages as a retirement funding strategy in Australia. The viability of reverse mortgages where elderly home owners effectively borrow against their housing equity depends strongly on house prices appreciating enough to offset the outstanding loan balance at the end of the loan tenure. This paper's findings indicate that after controlling for other influences, being aged 75 years or over lowers annual house price appreciation rate by almost 1.4 percentage points. Being aged 75 years or over also lowers home improvement expenditure by over AUD3,000 per year and this is found to be attributable to a decline in income during old age. The majority of elderly home owners want to protect at least half of their housing equity when considering participating in reverse mortgage programs, but given below-average house price appreciation rates during old age, the propensity of a 50\% equity protection declines sharply with age. In particular, single females aged 75 years or over are least able to protect at least half of their housing equity, with only around $15 \%$ able to do so by the end of a reverse mortgage loan tenure. The paper also finds that, worryingly, elderly home owners with characteristics associated with slower house price appreciation rates are over-represented among reverse mortgage borrowers in Australia, namely, those aged 75 years or over, single, living in apartments or residing in states with relatively slow house price growth.
\end{abstract}

Key words: house price appreciation; old age; home owner; reverse mortgage; Australia 


\section{Introduction}

For some time now, the rapid ageing of the population has driven changes in retirement and income support policies internationally. These changes reflect growing concern over the ability of governments to maintain fiscal sustainability in the face of the increases in fiscal expenditure on health care and income support that would accompany this significant demographic trend. In recent years in Australia, many policy initiatives have already been put into place to encourage financial independence among the elderly. These include gradual increments in women's minimum Age Pension eligibility age till it is aligned with men's minimum eligibility age of 65 years, implementation of the Deferred Pension Bonus plan that provides a bonus to eligible persons who defer their take-up of Age Pension, and increases in the compulsory superannuation preservation age (Ong, 2004). Most recently, the Australian government announced in its 2009 budget the lifting of the minimum Age Pension eligibility age to 67 years by 2023 (Swan, 2009).

In this context of rapid tightening of public provision and the government's increasing slant towards a policy of self-provision during retirement, the housing wealth of the elderly is emerging as a key asset that can be exploited to help fund their retirement during old age. This has spawned the development of reverse mortgages in countries such the United States, United Kingdom, Canada and Australia, which are designed to unlock illiquid wealth tied up in the elderly's housing equity to generate income. Elderly reverse mortgage borrowers effectively borrow against their housing equity with no repayments being made until the house is sold or the elderly borrower dies. Hence, the viability of reverse mortgages depends strongly on house prices appreciating enough to offset the outstanding loan balance at the end of the reverse mortgage tenure (Ong, 2008).

Australia has one of the highest rates of home ownership among OECD countries. The majority of elderly Australians are home owners who have paid off all or most of their mortgage. For most elderly Australian home owners, the value of their homes generally represents their most significant asset in old age. In a recent Australian government inquiry into long-term strategies to address population ageing, reverse mortgages were proposed as a method of unlocking savings in illiquid assets (House of Representatives Standing Committee on health and Ageing, 2005). Despite the slowdown in the housing market in the second half of 2008, the value of outstanding reverse mortgage loans grew by 13\% between June 2008 and June 2009 (Hickey et al., 2009b). At the end of June 2009, there were 38,000 reverse mortgage loans on issue in Australia, more than double the number of reverse mortgage loans in December 2005. In the first half of 2009, there were 2,350 new reverse mortgage borrowers. The total outstanding reverse mortgage loan balance in Australia has more than tripled from $\$ 0.85$ billion to $\$ 2.61$ billion between December 2005 and June 2009 (Hickey et al., 2009b).

This paper investigates whether the houses of elderly Australian home owners appreciate at the same rate as the average market rate and examines the issues this may raise for the use of reverse mortgages for retirement funding. This paper's investigation is of vital policy importance because despite the recent growth of the Australian reverse mortgage market, no study has ever empirically examined whether old age has a causal impact on a home owner's house price appreciation rate in Australia while studies from other countries such as the United States have found a negative association between old age and the growth of house prices (see, for example, Rodda and Patrabansh, 2007). If elderly home owners' houses appreciate slower than houses owned by younger home owners, then elderly home owners, who make decisions to borrow against their housing equity on the basis of average house price trends, run the risk of being left with little housing equity to draw on for financial emergencies or bequest purposes when they pass away. A situation where the elderly's houses are appreciating below the average market rate would 
exacerbate the risk that the elderly will exhaust their housing wealth earlier than expected, leaving them with insufficient resources to draw upon health care expenditure or accommodation costs, when they are no longer able to carry on living independent in their own homes due to old age. This creates a risk as government and the elderly's children may then have to intervene with additional income support and resources to support these elderly reverse mortgage borrowers. The increased risks that elderly reverse mortgage borrowers could be exposed to, as a result of under-estimating future growth in their house prices, needs to be quantified via empirical examination.

Section 2 briefly reviews the existing empirical literature on the links between old age and house price appreciation. The existing literature is sparse, and none make use of Australian data as this paper does. Section 3 addresses the question of whether old age has a causal impact on a home owner's house price appreciation rate. Section 4 examines the issues surrounding the use of reverse mortgage as a retirement funding strategy for Australian home owners. A final section provides concluding remarks.

\section{Background Literature}

A small number of studies from the United States have produced empirical estimates of elderly home owners' house price appreciation rates as compared to the general home owner population though none such study has been conducted in Australia. Using the Health and Retirement Study, Rodda and Patrabansh (2007) found that the houses of American elderly home owners aged 75 years or over appreciate in real dollars at a rate of 1 to 1.2 percentage points less per year than the houses of middle-aged home owners aged 50 to 74 years old. They also found that the houses of elderly home owners appreciate at a rate 2.4 percentage points less per year than do those of younger home owners using the American Census Bureau's Public User Microdata Sample. Davidoff (2004) estimated that American elderly home owners' house price appreciation rates were in general 3 percentage points lower than younger home owners using the American Housing Survey. Quercia (1997) examined the house price appreciation rates of housing-rich, income-poor home owners aged over 71 years old, that is, the cohort most resembling actual home owners who were likely to participate in a major United States reverse mortgage program, the Federal Housing Administration's (FHA) Home Equity Conversion Mortgage demonstration program. The study found that this elderly group experienced lower house price appreciation than assumed by the program.

The hypothesis that elderly home owners' houses appreciate at below-average rates has been linked to overseas findings that elderly home owners are likely to spend less on home maintenance and repairs than younger home owners. In a study of elderly home owners' expenditure on home maintenance, Davidoff (2004) found that home owners aged over 75 years spend approximately USD270 per year less on routine home maintenance and USD1100 less on all home improvement than younger owners of similar properties. Goodman and Thibodeau (1997) found that variances in house values increase as buildings age. The study postulated that this dwelling-age-related heteroskedasticity could be related to the probability and level of renovation or maintenance that took place over the age of the house. Rodda and Patrabansh (2007) postulated that elderly home owners are less likely to have updated the style of their house. This can result in the house acquiring unusual features as it ages. Capozza et al. (2005) noted as a house becomes atypical relative to other houses in the market, this can lower demand and increase search costs associated with finding a buyer. Appraisers may then have difficulty finding comparable houses in the neighbourhood. As a result, the appraised value of the house may be discounted. 
Most house price data that are publicly available are based on home owners' self-reported values. The literature contains contradictory findings on whether home owners' self-reported values are reliable estimates of the market values of their homes. Goodman and Ittner (1992) and DiPasquale and Somerville (1995) found that home owners' self-reported values are generally somewhat higher than market values. However, Kennickell and Starr-McCluer (1997) and Bucks and Penns (2006) have found that most report their house values accurately. Kiel and Zabel (1999) found that home owners with short tenure overvalue their homes by $8.4 \%$, but those with longer tenure overvalue their houses by only $3.3 \%$. Most of the existing studies linking home owner age to house price appreciation have relied on data provided by home owners (see Quercia, 1997; Davidoff, 2004; Rodda and Patrabansh, 2007). This paper follows existing studies by using self-reported house price data. However, as far as possible steps are taken to account for any potential biases in self-reported values.

\section{Do House Prices Appreciate Slower in Old Age?}

This study invokes longitudinal analysis using an Australian panel dataset to examine the effect of old age on house price appreciation, defined as the proportionate change in real house price between two adjacent years. The use of a panel dataset is of crucial importance to the present analysis as it allows fixed personal and property-specific characteristics to be controlled for so that changes in house prices are not confounded by compositional changes in the housing market and population of home owners over time. The analysis is conducted using the 2001-07 Household, Income and Labour Dynamics in Australia (HILDA) Survey. This panel survey contains rich information on socio-demographic and economic characteristics of the interviewees, along with their housingrelated characteristics, such as house values, dwelling type and geographical locations. The HILDA Survey is the only panel survey available in Australia that is both comprehensive in terms of housing and other socio-demographic variables and nationally representative. It is therefore the most suitable panel dataset available that allows nationally representative comparisons of the house price trends of elderly and non-elderly households over time. The panel was established through the wave 1 interviews of a randomly selected sample of 7682 households in 2001. As far as possible, the 2001 respondents are interviewed in each subsequent year. The latest wave of survey currently available is wave 7 .

A sample is formed which comprises an unbalanced panel of owner-occupied houses, each of which is owned by a responding interviewee in waves $t$ and $t+1$. This provides house values for the same home owner at two distinct points in time. The term 'house' covers separate, semi-detached, row or terrace houses, townhouses, flats, apartments and units, but excludes mobile dwellings and dwellings that are attached to other buildings. Examples of mobile dwellings are caravans, tents, cabins or houseboats and attachments include flats that are attached to shops etc. Only houses occupied by a single income unit are selected as it is not possible to directly identify in every wave the income unit that owns the house in houses occupied by multiple income units. ${ }^{1}$ The resulting sample is comprised of 5,750 owner-occupied homes. As there are repeated observations for each home, the final sample is a pooled sample of 21,977 observations. Elderly households are defined as households in which the oldest member is aged 60 and over. The age 60 years is used as the age break for defining the term 'elderly' because while the government is lifting the minimum Age Pension eligibility age to 67 years, most Australians retire before reaching this age, and the typical

\footnotetext{
${ }^{1}$ An income unit is a person or group of persons related by marriage or parent-child relationship who live within the same household and share income (Australian Bureau of Statistics, 1997). A household may comprise several groups of unrelated income units living together. About $85 \%$ of the owner-occupied houses in the sample are occupied by single income units.
} 
retirement age has been cited as between 58 and 61 years (Senior Australians Equity Release Association of Lenders, 2008; Martin, 2009). Moreover, reverse mortgage products are generally available to those aged 60 years and over (Australian Securities and Investments Commission, 2009). The HILDA Survey does not provide data on house market resale values, so the study relies on self-reported house values. House prices are converted to real dollars using the Australian Bureau of Statistics' capital city Consumer Price Index (CPI) series, that is, to calculate the house price appreciation rate between waves $t$ and $t+1$, the house price in wave $t+1$ is converted to wave $t$ dollars.

The model specification in this paper represents a novel contribution to the literature on the house price appreciation rates of the elderly. Existing papers such as Rodda and Patrabansh (2007) and Davidoff (2004) that have addressed this research question have adopted modelling strategies that compared house prices only at the beginning and end of an observation period, ignoring changes in house prices during the period.

To isolate the age effect on house price appreciation rate, the study explicitly exploits the panel feature of the data by modelling the real house price appreciation rate between waves $t$ and $t+1$ as a function of the home owner's age and other controls at $t$ :

$$
H A P_{t+1}=f A g e_{t}, l_{t}, P_{t}, X_{t}^{-}
$$

where $H A P_{t+1}=$ house price appreciation rate between $t$ and $t+1, A g e_{t}$ represents age variables, $l_{t}$ is the length of tenure in the home, $P_{t}$ is a vector of property characteristics and $X_{t}$ is a vector of personal characteristics of the home owner in wave $t$.

The home owner age effect is represented by dummy variables that represent whether a home owner is aged 65-69 years, 70-74 years, or 75 year or over. These age coefficients represent the percentage point impact on annual house price appreciation rates of being elderly.

A length of tenure variable, $l_{t}$, is also included, defined as the number of years the home owner had lived in his/her home by wave $t$. This variable helps capture any systematic differences between self-reported and market values that may exist as a result of older home owners having longer tenures. Tenure length is also likely to be correlated with building age. As the latter is not available from the HILDA Survey, the tenure length variable provides a crude proxy for building age.

The vector of property characteristics, $P_{t}$, includes dwelling type, number of bedrooms and geographical variables. Capital city, rest of state and regional variables capture differences in housing market conditions across locations in Australia. If elderly home owners are disproportionately concentrated in neighbourhoods with low house appreciation rates, the effect of the lower appreciation of these neighbourhoods will be captured in the age coefficient. In order to minimise this bias, neighbourhood characteristics should be included in the model as controls. Neighbourhood variables such as whether noise from traffic, airplanes, trains or industry, and whether occurrences of property damage and burglary or theft are common in the neighbourhood are available from the HILDA Survey. However, these variables are excluded as they turn out to be insignificant when introduced into the model. Ethnicity variables, when introduced into the models as proxies for neighbourhood characteristics, also turn out to be insignificant and are excluded. Davidoff (2004) used building age and square footage as proxies for neighbourhood characteristics. The study also found generally insignificant effects for these neighbourhood proxies.

In a household where the house is owned by a couple, it is assumed that both members of the couple jointly own the home, so the home owner's personal characteristics are the characteristics of the older member of the couple, such as marital status, health and cognitive abilities. An indicator of 
whether the home owner had cognitive problems helps to control for potential biases in selfreported house values that are due to cognitive problems. Education, and the number of earners and income of the income unit are also included to reflect human capital and economic characteristics that can potentially affect home owners' house price appreciation rates. Number of earners and income are measured on an income unit basis because income sharing takes place among members of the home owner income unit (Australian Bureau of Statistics, 1997).

The model specification is a random effects model. A random effects model has been selected over a pooled model by the Breusch and Pagan Lagrangian multiplier test for random effects which rejects the null hypothesis of no random effects. A random effects model has also been selected over a fixed effects model because the Hausman test fails to reject the null hypothesis that the $1 \%$, $5 \%$ or $10 \%$ levels that coefficients obtained under the random effects model is consistent.

Table 1 reports the mean house price appreciation rates of elderly vs non-elderly home owners in each year in the sample. The table shows some fluctuations in the real house price appreciation rates over the period. House price growth peaked in 2001-02 and 2002-03 for all age groups during the house price boom, rising from a mean of $10.4 \%$ to $12.5 \%$ between 2001-02 and 2002-03. In 200304 , the housing market remained resilient with real house prices growing on average by $9 \%$. However, average house price appreciation rates dipped to below 3\% in 2004-05 and 2005-06, finally rising to a mean of 5.4\% in 2006-07.

During the pre-2003 house price boom and in 2006-07 when house prices rose again, it is apparent that younger home owners aged under 60 years experienced stronger house price growth than older home owners. A somewhat similar trend was noticeable in 2003-04, when housing markets remained strong, though during this year it was the oldest group aged 75 years or over that suffered weaker house price growth than those aged under 75 years. In the intervening years of 2004-05 and 2005-06 when real house price growth was sluggish in comparison to other years, there was not noticeably significant trend across age groups. Clearly, regression analysis is required to isolate the age effect on house price appreciation rates.

Table 1: House price appreciation rate, 2001-07, per cent

\begin{tabular}{lcccccc}
\hline Age band & $2001-02$ & $2002-03$ & $2003-04$ & $2004-05$ & $2005-06$ & $2006-07$ \\
\hline Mean & & & & & & \\
Under 60 years & 11.0 & 13.1 & 9.6 & 3.0 & 2.8 & 6.0 \\
60-64 years & 8.0 & 13.0 & 9.5 & 3.5 & 3.1 & 4.4 \\
65-69 years & 9.7 & 11.8 & 9.7 & 1.5 & 4.0 & 3.6 \\
70-74 years & 10.9 & 11.5 & 9.7 & 2.5 & 2.1 & 3.9 \\
75 years or over & 8.3 & 9.0 & 6.9 & 2.2 & 3.2 & 5.0 \\
Total & 10.4 & 12.5 & 9.3 & 2.8 & 2.9 & 5.4 \\
\hline
\end{tabular}

Source: Author's own estimates from HILDA Survey waves 1-7

Table 2 reports the summary statistics of the variables used in the regression model. As the sample is a pooled sample where each home owner has repeated observations, the summary statistics are calculated only once for each home owner, at the point when they are first observed in the sample. Over one-quarter of the home owners in the sample are elderly. As indicated by the calendar year variables, over two-thirds of home owners are observed for the first time in the first wave of the HILDA Survey, that is, 2001. On average, home owners have occupied their houses for 11 years and most live in separate houses that have at least three bedrooms. Most home owners live in major cities or inner regional areas, and home owners tend to be drawn from the Eastern states (New South Wales, Victoria and Brisbane) and least from the territories. This is consistent with the population distribution across Australia. 70\% of home owners are couples. Approximately the same proportion have no children aged under 15 years, though some of these may have older children 
who are less or not dependent on them. One-quarter have a disability or long-term health condition though a much small proportion (less than $4 \%$ ) have reported cognitive problems. Over half have some form of post-school qualifications. Most home owners live in households where there are is at least 1 earner in the income unit; again not surprising as earnings are required to finance mortgage repayments for owner purchasers who have an outstanding loan against their home. The average gross income unit income amounts to $\$ 61,000$ per year. This is slightly lower than the average of $\$ 65,000$ per year from all persons (home owners and non-home owners) in the HILDA Survey in 2001. This is because home owners are more likely to be older and to have retired, resulting in lower income than the general population.

Table 2: Summary statistics of variables used in the house price appreciation rate model, 2001-06, mean for home owners / houses when first observed, per cent unless stated otherwise

\begin{tabular}{|c|c|c|}
\hline Variables & & Mean \\
\hline \multirow[t]{5}{*}{ Age band: } & Aged under 60 years & 72.1 \\
\hline & Aged $60-64$ years & 7.6 \\
\hline & Aged $65-69$ years & 6.0 \\
\hline & Age $70-74$ years & 5.8 \\
\hline & Age 75 years or over & 8.5 \\
\hline \multirow[t]{6}{*}{ Calendar year: } & 2001 & 65.6 \\
\hline & 2002 & 12.0 \\
\hline & 2003 & 7.5 \\
\hline & 2004 & 5.1 \\
\hline & 2005 & 5.2 \\
\hline & 2006 & 4.7 \\
\hline Length of tenure: & Number of years of residence in the house & 11.1 years \\
\hline \multirow[t]{3}{*}{ Dwelling type: } & Separate house & 88.5 \\
\hline & Semi-detached, row or terrace house, townhouse & 6.0 \\
\hline & Flat, unit or apartment & 5.4 \\
\hline \multirow[t]{3}{*}{ Number of bedrooms: } & Less than three bedrooms & 15.8 \\
\hline & Three bedrooms & 48.5 \\
\hline & Four or more bedrooms & 35.7 \\
\hline \multirow[t]{3}{*}{ Region: ${ }^{a}$} & Major city & 60.5 \\
\hline & Inner region & 26.0 \\
\hline & Outer region, remote or very remote & 13.5 \\
\hline \multirow[t]{13}{*}{ Capital city / rest of state: } & Sydney (New South Wales capital city) & 15.6 \\
\hline & Rest of New South Wales & 14.5 \\
\hline & Melbourne (Victoria capital city) & 17.8 \\
\hline & Rest of Victoria & 8.3 \\
\hline & Brisbane (Queensland capital city) & 8.5 \\
\hline & Rest of Queensland & 10.8 \\
\hline & Adelaide (South Australia capital city) & 6.1 \\
\hline & Rest of South Australia & 2.8 \\
\hline & Perth (Western Australia capital city) & 7.6 \\
\hline & Rest of Western Australia & 2.9 \\
\hline & Tasmania & 2.9 \\
\hline & Northern Territory & 0.5 \\
\hline & Australian Capital Territory & 1.8 \\
\hline \multirow[t]{3}{*}{ Marital status: } & Couple & 68.8 \\
\hline & Single female & 20.3 \\
\hline & Single male & 10.9 \\
\hline \multirow[t]{4}{*}{ Number of children: } & No children aged under 15 years & 69.1 \\
\hline & 1 child aged under 15 years & 11.4 \\
\hline & 2 children aged under 15 years & 12.9 \\
\hline & 3 or more children aged under 15 years & 6.5 \\
\hline \multirow[t]{2}{*}{ Health: } & Has disability or long-term health condition & 24.5 \\
\hline & Has cognitive problems & 3.7 \\
\hline \multirow[t]{2}{*}{ Educational qualifications: } & University degree or higher & 22.2 \\
\hline & Other post-school qualifications & 34.5 \\
\hline
\end{tabular}




\begin{tabular}{lll}
\hline Variables & & Mean \\
\hline \multirow{3}{*}{ Economic characteristics: } & No post-school qualifications & 43.3 \\
& No wage earners in income unit & 28.3 \\
& 1 wage earner in income unit & 33.1 \\
& 2 wage earners in income unit & 38.6 \\
& Gross income unit income / $\$ 10,000$ & $\$ 6.1$ \\
\hline
\end{tabular}

Source: Author's own estimation from HILDA Survey waves 1-7

Notes:

a. The regional classifications are derived from the Accessibility/Remoteness Index of Australia (ARIA) scores from the 2001 Census. The ARIA index categorises non-contiguous geographical areas within each state or territory into areas that share common remoteness characteristics (Australian Bureau of Statistics, 2001).

The regression results are presented in table 3. The age coefficients show that after controlling for other influences, being aged 75 years or over lowers annual house price appreciation rate by almost 1.4 percentage points; this effect is highly significant at the $1 \%$ level. The average house price appreciation rate in the pooled sample is $7.2 \%$. Hence, the 1.4 percentage point discount attributable to old age represents almost a $20 \%$ discount when expressed as a proportion of the average house price appreciation rate. The median house price in the sample is $\$ 300,000$. Holding all other variables constant, a 7.2\% appreciation rate would indicate that real median house price would have risen by $\$ 21,600$ by the following year. However, the impact of old age of 75 years or over is to result in a real house price growth of only $\$ 17,400$, a discount of $\$ 4,200$ annually.

The calendar year variables are all strongly significant and indicate that house price appreciation peaked in 2002, as observed from table 1 as well. For every additional year of tenure in the home, annual house price appreciation rate falls by 0.04 percentage points. There is a 1.2 percentage point discount in house price appreciation rate associated with residing in a flat, unit or apartment. Larger dwellings (as represented by the number of bedrooms) and houses in outer regions appreciate at lower rates than smaller dwellings and houses in inner regional or city areas respectively though the size of dwelling effect is only weakly significant. The state and capital city variables are generally highly significant, with housing market conditions appearing to have been particularly strong in all areas as compared to the default location of Sydney when other influences are controlled for.

While the age and property variables are largely significant with the expected coefficient signs, the links between the socio-economic characteristics of home owners and house price appreciation rates are less apparent. Controlling for other factors, couples experience house price appreciation rates that are almost a percentage point higher than singles. However, the number of children has no impact on house price appreciation rates. The health variables are insignificant, though the health variables are correlated with age. The correlation statistics between the health measures and most of the age bands (65-69, 70-74 and 75 years or over) are significant at the $1 \%$ level and the magnitude of the correlation statistic increases as the age band rises. This finding supports Rodda and Patrabansh (2007) who did not find the cognitive status score coefficient to be significant in their house price appreciation equation using the American Health and Retirement Study.

Educational qualifications do not appear to matter. The number of earners in the income unit has a negative impact on house price appreciation rate; this may be capturing a wealth effect, that is, some retirees may have higher wealth levels than the non-retired. However, as wealth variables are only available in waves 2 and 6 of the HILDA Survey and not in other waves, they have not been included in the model. Furthermore, the negative number of earners effect is partly offset by a positive income effect whereby each additional $\$ 10,000$ of income raises the house price appreciation rate by 0.04 percentage points. 
Table 3: Random effects model of annual house price appreciation rate, 2001-0 $7^{\mathrm{ab}}$

\begin{tabular}{|c|c|c|c|}
\hline Explanatory variables & & Coefficient & $\begin{array}{r}\text { Standard } \\
\text { error } \\
\end{array}$ \\
\hline \multirow[t]{4}{*}{ Age: } & Aged $60-64$ years & -0.697 & 0.430 \\
\hline & Aged $65-69$ years & $-0.919 *$ & 0.483 \\
\hline & Age $70-74$ years & -0.641 & 0.529 \\
\hline & Age 75 years or over & $-1.388 * * *$ & 0.490 \\
\hline \multirow{5}{*}{ Calendar year: } & 2002 & $2.088 * * *$ & 0.376 \\
\hline & 2003 & $-1.122 * * *$ & 0.374 \\
\hline & 2004 & $-7.576 * * *$ & 0.372 \\
\hline & 2005 & $-7.392 * * *$ & 0.373 \\
\hline & 2006 & $-5.023 * * *$ & 0.373 \\
\hline Length of tenure: & Number of years of residence in the house & $-0.040 * * *$ & 0.010 \\
\hline \multirow[t]{2}{*}{ Dwelling type: } & $\begin{array}{l}\text { Semi-detached, row or terrace house, } \\
\text { townhouse }\end{array}$ & -0.419 & 0.514 \\
\hline & Flat, unit or apartment & $-1.169 * *$ & 0.578 \\
\hline \multirow{2}{*}{ Number of bedrooms: } & Less than three bedrooms & -0.063 & 0.361 \\
\hline & Four or more bedrooms & $-0.441 *$ & 0.249 \\
\hline \multirow[t]{2}{*}{ Region: } & Inner region & -0.045 & 0.401 \\
\hline & Outer region, remote or very remote & $-1.243 * *$ & 0.504 \\
\hline \multirow[t]{12}{*}{ Capital city / rest of state: } & Rest of New South Wales & $2.071 * * *$ & 0.482 \\
\hline & Melbourne & $1.781 * * *$ & 0.372 \\
\hline & Rest of Victoria & $1.457 * *$ & 0.575 \\
\hline & Brisbane & $5.043 * * *$ & 0.466 \\
\hline & Rest of Queensland & $4.439 * * *$ & 0.542 \\
\hline & Adelaide & $4.953 * * *$ & 0.507 \\
\hline & Rest of South Australia & $2.356 * * *$ & 0.820 \\
\hline & Perth & $6.857 * * *$ & 0.484 \\
\hline & Rest of Western Australia & $4.585 * * *$ & 0.832 \\
\hline & Tasmania & $5.224 * * *$ & 0.801 \\
\hline & Northern Territory & $6.456 * * *$ & 1.728 \\
\hline & Australian Capital Territory & $3.564 * * *$ & 0.865 \\
\hline \multirow[t]{2}{*}{ Marital status: } & Couple & $0.922 * *$ & 0.393 \\
\hline & Single female & 0.232 & 0.419 \\
\hline Number of children: & Number of children aged under 15 years & 0.061 & 0.127 \\
\hline \multirow[t]{2}{*}{ Health: } & $\begin{array}{l}\text { Has disability or long-term health } \\
\text { condition }\end{array}$ & 0.380 & 0.265 \\
\hline & Has cognitive problems & -0.809 & 0.614 \\
\hline \multirow[t]{2}{*}{ Educational qualifications: } & University degree or higher & -0.397 & 0.303 \\
\hline & Other post-school qualifications & 0.125 & 0.255 \\
\hline \multirow[t]{2}{*}{ Economic characteristics: } & Number of wage earners in income unit & $-0.674 * * *$ & 0.210 \\
\hline & Gross income unit income $/ \$ 10,000$ & $0.042 * *$ & 0.021 \\
\hline Constant & & $8.467 * * *$ & 0.593 \\
\hline \multirow[t]{5}{*}{ Regression diagnostics: } & Number of observations & 21,977 & \\
\hline & Number of groups & 5,750 & \\
\hline & Wald $\mathrm{Chi}^{2}(37)$ & $1,629.43 * * *$ & \\
\hline & Hausman test $\mathrm{Chi}^{2}(37)$ & 45.92 & \\
\hline & $\begin{array}{l}\text { Breusch and Pagan Lagrangian multiplier } \\
\text { test for random effects } \mathrm{Chi}^{2}(1)\end{array}$ & $304.70 * * *$ & \\
\hline
\end{tabular}

Source: Author's own estimation from HILDA Survey waves 1-7

Notes:

*** $P<0.01 ; * * P<0.05 ; * P<0.10$

a. The length of tenure, number of children and income variables are continuous variables. All other variables are binary variables which equal one if the characteristics is applicable, and zero otherwise.

b. The omitted categories for the binary variables are: calendar year 2001, separate house, three bedrooms, major city, Sydney, single male, no disability, no cognitive problems and no post-school qualifications.

The analysis is extended by examining whether there is an age effect on home maintenance, renovations or repairs expenditure by home owners, defined broadly as 'home improvement'. This investigation is important because the hypothesis that elderly home owners' houses appreciate at 
below-average rates has been linked to overseas findings that elderly home owners are likely to spend less on home improvement than younger home owners.

In an analysis of elderly home owners' expenditure on home improvement, Davidoff (2004) found that home owners aged over 75 years spend approximately USD270 per year less on routine home maintenance and USD1100 less on all home improvement than younger owners of similar properties. According to estimates from the HILDA Survey, home owners aged under 65 years spent an average of $\$ 4,740$ on home improvement expenditure in 2007. However, those aged 65-59 and 70-74 years spent an average of $\$ 1,590$ and $\$ 2,520$ only. The oldest group aged 75 years or over spent $\$ 920$ on home expenditure in 2007 , less than one-fifth the amount spent by those aged under 65 years.

Annual expenditure on home improvement by home owners is modelled as a function of the home owner's age and other controls in a cross-sectional model using the 2007 HILDA Survey: ${ }^{2}$

$$
M=f\left(A g e, l, P, X_{-}^{-}\right.
$$

where $M$ represents annual expenditure on home improvement expressed in thousands of dollars, and the other variables are as defined in equation (1). As $20 \%$ of home owners reported zero expenditure on home improvement, a tobit specification is used.

Two models are estimated and reported in table 4. Model 1 excludes economic characteristics, while model 2 includes them. This is done in order to ascertain whether any negative age effect observed in Model 1 is a result of an income effect. Model 1 shows that being aged 75 years or over reduces annual home improvement expenditure by $\$ 3,130$ holding other factors constant. However, when economic characteristics are introduced in Model 2, the negative effect associated with being aged 75 years or over, previously significant at the $5 \%$ level, becomes insignificant. Hence, it can be inferred that the negative old age effect on home improvement expenditures is due to a decline in income as home owners enter old age. Home improvement expenditure models presented in Davidoff (2004) paper finds a negative effect associated with old age on home improvement expenditure, but the study does not include economic variables such as income in its models.

It can then be surmised that the impact of reduced home improvement expenditure in old age on house price appreciation rates works largely through the income variable in the house price appreciation rate model. The remaining significant old age effect represented by the age 75 years or over dummy variable may be explained by some of the hypotheses put forward by the overseas literature that are more related to the tastes and preferences of elderly home owners. For example, elderly home owners may have tastes in house features that are not typical of newer houses in the neighbourhood. Rodda and Patrabansh (2007) postulated that elderly home owners are less likely to have updated the style of their house resulting in the house acquiring unusual features as it ages. Capozza et al. (2005) noted as a house becomes atypical relative to other houses in the market, this can lower demand and increase search costs associated with finding a buyer. Appraisers may then have difficulty finding comparable houses in the neighbourhood. As a result, the appraised value of the house may be discounted. Davidoff (2004) cited anecdotal evidence that suggests that some elderly home owners may be fearful of contract-out home improvement and the disruption this may cause to their homes. A lack of awareness among elderly home owners of the extent to which home improvement expenditures may increase their house prices may be another factor (Davidoff, 2004).

\footnotetext{
${ }^{2}$ Data on home maintenance, renovations and repairs expenditure are only available in the 2005, 2006 and 2007 HILDA Survey. Only expenditure data from the latest wave of the survey is used as the expenditure data is not available in all seven waves of the survey and the analysis does not require the use of a panel model.
} 
Table 4: Tobit model of annual expenditure on home improvement, $2007^{\mathrm{ab}}$

\begin{tabular}{|c|c|c|c|c|c|}
\hline \multirow{2}{*}{\multicolumn{2}{|c|}{ Explanatory variables }} & \multirow{2}{*}{\multicolumn{2}{|c|}{ Model 1}} & \multirow{2}{*}{\multicolumn{2}{|c|}{ Model 2}} \\
\hline & & & & & \\
\hline Age: & Aged $60-64$ years & $\begin{array}{l}\text { Coef. } \\
1.132\end{array}$ & $\begin{array}{r}\begin{array}{r}\text { Standard } \\
\text { error }\end{array} \\
1.082\end{array}$ & $\begin{array}{l}\text { Coef. } \\
1.675\end{array}$ & $\begin{array}{r}\begin{array}{r}\text { Standarc } \\
\text { erro }\end{array} \\
1.119\end{array}$ \\
\hline & Aged $65-69$ years & -1.509 & 1.193 & -0.350 & 1.328 \\
\hline & Age $70-74$ years & -1.159 & 1.317 & 0.326 & 1.473 \\
\hline & Age 75 years or over & $-3.130 * *$ & 1.223 & -1.711 & 1.394 \\
\hline Length of tenure: & $\begin{array}{l}\text { Number of years of residence in } \\
\text { the house }\end{array}$ & $-0.059 * *$ & 0.027 & $-0.055^{* *}$ & 0.027 \\
\hline \multirow[t]{2}{*}{ Dwelling type: } & $\begin{array}{l}\text { Semi-detached, row or terrace } \\
\text { house, townhouse }\end{array}$ & -0.514 & 1.427 & -0.627 & 1.426 \\
\hline & Flat, unit or apartment & $-5.283 * * *$ & 1.677 & $-5.329 * * *$ & 1.674 \\
\hline \multirow{2}{*}{ Number of bedrooms: } & Less than three bedrooms & -0.205 & 1.023 & -0.208 & 1.022 \\
\hline & Four or more bedrooms & $1.914 * * *$ & 0.670 & $1.667 * *$ & 0.673 \\
\hline \multirow[t]{2}{*}{ Region: } & Inner region & -1.370 & 1.074 & -1.209 & 1.073 \\
\hline & $\begin{array}{l}\text { Outer region, remote or very } \\
\text { remote }\end{array}$ & $-2.275 *$ & 1.367 & -2.071 & 1.367 \\
\hline \multirow{12}{*}{$\begin{array}{l}\text { Capital city / rest of } \\
\text { state: }\end{array}$} & Rest of New South Wales & $-2.399 *$ & 1.335 & $-2.253^{*}$ & 1.334 \\
\hline & Melbourne & $-2.015 *$ & 1.055 & $-1.938^{*}$ & 1.053 \\
\hline & Rest of Victoria & $-2.904 *$ & 1.586 & $-2.810^{*}$ & 1.585 \\
\hline & Brisbane & -1.305 & 1.269 & -1.164 & 1.268 \\
\hline & Rest of Queensland & -2.058 & 1.460 & -1.885 & 1.458 \\
\hline & Adelaide & $-2.898 * *$ & 1.408 & $-2.719 * *$ & 1.408 \\
\hline & Rest of South Australia & -1.039 & 2.179 & -0.975 & 2.177 \\
\hline & Perth & $-2.205 *$ & 1.334 & -2.042 & 1.333 \\
\hline & Rest of Western Australia & -1.898 & 2.276 & -1.694 & 2.274 \\
\hline & Tasmania & -2.133 & 2.156 & -2.007 & 2.154 \\
\hline & Northern Territory & 2.703 & 4.205 & 2.146 & 4.203 \\
\hline & Australian Capital Territory & $-5.487 * *$ & 2.333 & $-5.558 * *$ & 2.330 \\
\hline \multirow[t]{2}{*}{ Marital status: } & Couple & $4.526 * * *$ & 1.068 & $3.488 * * *$ & 1.141 \\
\hline & Single female & 1.727 & 1.210 & 1.855 & 1.210 \\
\hline Number of children: & $\begin{array}{l}\text { Number of children aged under } \\
15 \text { years }\end{array}$ & 0.090 & 0.371 & 0.098 & 0.372 \\
\hline \multirow[t]{2}{*}{ Health: } & $\begin{array}{l}\text { Has disability or long-term } \\
\text { health condition }\end{array}$ & -0.658 & 0.723 & -0.301 & 0.734 \\
\hline & Has cognitive problems & -1.363 & 1.990 & -1.101 & 1.988 \\
\hline \multirow{4}{*}{$\begin{array}{l}\text { Educational } \\
\text { qualifications: } \\
\text { Economic } \\
\text { characteristics: }\end{array}$} & University degree or higher & $5.680 * * *$ & 0.803 & $5.124 * * *$ & 0.818 \\
\hline & Other post-school qualifications & $1.453 * *$ & 0.707 & $1.342 *$ & 0.707 \\
\hline & $\begin{array}{l}\text { Number of wage earners in } \\
\text { income unit }\end{array}$ & & & 0.931 & 0.586 \\
\hline & $\begin{array}{l}\text { Gross income unit income / } \\
\$ 10,000\end{array}$ & & & $0.116 * * *$ & 0.040 \\
\hline \multirow{3}{*}{$\begin{array}{l}\text { Constant } \\
\text { Regression } \\
\text { diagnostics: }\end{array}$} & & -1.223 & 1.475 & $-2.963 *$ & 1.592 \\
\hline & Number of observations & 4,026 & & 4,026 & \\
\hline & Wald $\mathrm{Chi}^{2}(28 ; 30)$ & $229.02 * * *$ & & $241.95 * * *$ & \\
\hline
\end{tabular}

Source: Author's own estimation from HILDA Survey waves 1-7

Notes:

*** $P<0.01 ; * * P<0.05 ; * P<0.10$

a. The length of tenure, number of children and income variables are continuous variables. All other variables are binary variables which equal one if the characteristics is applicable, and zero otherwise.

b. The omitted categories for the binary variables are: separate house, three bedrooms, major city, Sydney, single male, no disability, no cognitive problems and no post-school qualifications. 


\section{Issues for the Use of Reverse Mortgage as a Retirement Funding}

\section{Strategy}

In this section two key issues surrounding the use of reverse mortgage as a retirement funding instrument are examined in the context of slower house price appreciation rates among home owners in old age. The first issue investigated relates to the protection of housing equity. According to a reverse mortgage study conducted by SEQUAL (2008), the majority of over-60s want to protect more than half of their housing equity. Is this possible in a reverse mortgage market such as Australia's? Secondly, the issue of self-selection into reverse mortgage programs is important because reverse mortgages are self-selecting programs, that is, some elderly home owners choose to become reverse mortgage borrowers while others do not. If elderly home owners who choose to participate in reverse mortgage programs possess personal and property characteristics that are correlated with slower house price growth, e.g. they are more likely to be aged 75 years or over or are single, then there is cause to worry that reverse mortgages may not be a viable retirement funding strategy as these home owners are more likely to be exposed to losing a greater amount of housing equity than they had expected. If, on the other hand, those who choose to participate in reverse mortgage programs possess personal and property characteristics that are correlated with higher house price growth, e.g. they are more likely to be aged 60-74 years or are partnered, then there is less cause to worry that reverse mortgages may not be a viable retirement funding strategy.

In order to investigate the propensity of elderly home owners to protect at least half of their housing equity, this requires the computation of two important variables - the elderly reverse mortgage borrower's house value at the end of the loan tenure and the outstanding loan balance at the end of the tenure. Here the analysis is restricted to the latest cross-section sample of households where the home owners are aged 60-90 years in wave 7 of the HILDA Survey, giving a sample of elderly 1,316 home owners in 2007. If all of these home owners entered into reverse mortgage contracts in 2007 and a significant proportion are found to have an outstanding loan balance that are more than $50 \%$ of their house value at the end of their loan tenure, then it indicates that reverse mortgages are unlike to meet elderly home owners' preferences that more than half of their equity be protected. ${ }^{3}$

The regression estimates reported in the previous section are used to predict the annual house price appreciation rate of the 1,316 elderly home owners in 2007. For home owners observed multiple times in the regression sample, the average of their predicted house price appreciation rates is taken. The predicted house price appreciation rates are used to forecast these home owners' house prices at the end of their loan tenure. Life expectancy and hence expected loan tenure is derived from the Australian Bureau of Statistics' (2007) life tables (see appendix table A1). In the case of couples, the age of the younger partner is used to calculated life expectancy as the younger partner is more likely to remain longer in the home.

The outstanding loan balance at the end of the tenure, is calculated as follows:

$$
L_{t}=L_{07}<+r / 12^{m}
$$

where $L_{t}$ represents the outstanding loan balance at the end of the loan tenure, $L_{07}$ represents the maximum loan advance available at the start of the tenure, $r$ is the reverse mortgage annual interest

\footnotetext{
${ }^{3}$ The oldest age of home owners is capped at 90 years because it is unlikely that very old home owners would enter into reverse mortgages given many would find it difficult to continue ageing in their own homes due to physical frailty and the more complex care requirements associated with very old age. Australian lenders are also unlikely to offer reverse mortgage to very old home owners. Bluestone Equity Release, Australia's first specialist reverse mortgage company, offers reverse mortgage loans to elderly home owners aged up to 90 years (Bluestone Equity Release, 2008a).
} 
rate which is monthly compounded, and $m$ denotes months.

Given the growth in the number of reverse mortgage products offered by financial institutions in Australia in recent years, this paper makes a significant contribution by utilising a reverse mortgage model template that is based on the general features of reverse mortgage products currently offered in Australia. As the assumed start year of loan advance is 2007, interest rates prevailing around that period are used. Information released by Bluestone Equity Release indicates that reverse mortgage loans were around 10-11\% per annum around that period (Bluestone Equity Release, 2008b). Major banks in Australia offered reverse mortgage products at interest rates or over $10.5 \%$ (Commonwealth Bank of Australia, 2008; St. George Bank, 2008). Hence, this paper employs an interest rate $(r)$ of $11 \%$. The maximum loan advance available at the start of the loan tenure $\left(L_{07}\right)$ is calculated using the 2007 maximum loan advance factors as a proportion of house value published by SEQUAL (see appendix table A2). These loan advance factors indicate the maximum proportion of house value that can be taken out as a loan advance ranges from $15 \%$ to $40 \%$.

Figure 1 illustrates the average likelihood of elderly home owners in each age band being able to protect at least half of their housing equity by the end of their loan tenure if they were to enter into reverse mortgages. It is clear that the propensity of protecting at least half of one's housing equity declines sharply with age, regardless of marital status. Among the partnered, this propensity drops from almost $60 \%$ to $20 \%$ from the $60-64$ years age band to those aged 75 years or over. Similar trends are observed for the singles. Single females aged 75 years or over are least able to protect at least half of their housing equity, with only around $15 \%$ able to do so at the end of the loan tenure. This is a worrying finding because women are disproportionately represented within the older population, comprising two-thirds of those aged over 85 years (Sharp and Austen, 2007).

Furthermore, the risks of inadequate retirement income are particularly high for women, due to lower lifetime incomes and superannuation accumulations, and longer life expectancy than men (Jefferson and Preston, 2005).

Figure 1: Probability of protecting at least half of housing equity by the end of the loan tenure, by age band and marital status, per cent

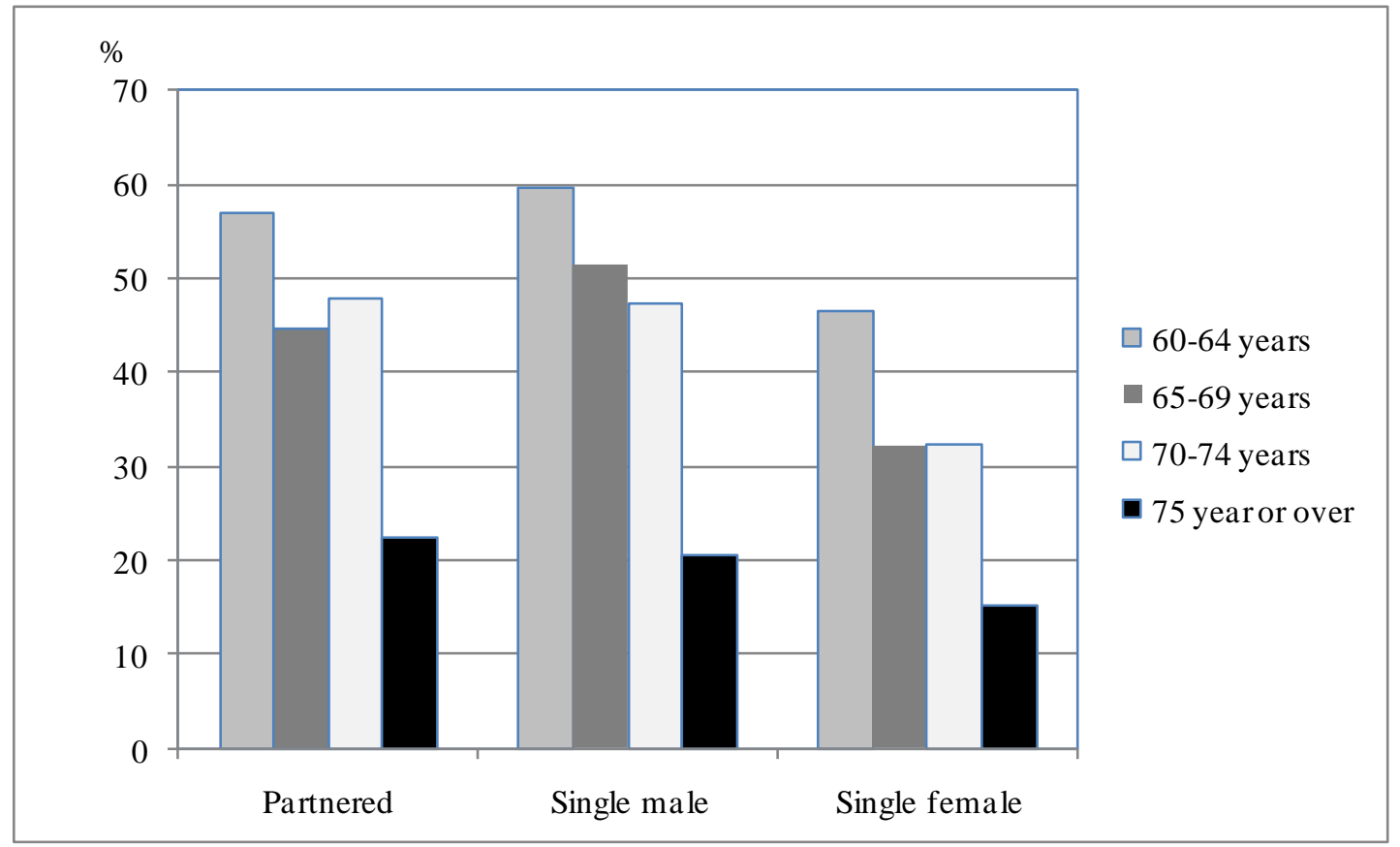

Source: Author's own estimates from HILDA Survey wave 7 
The approach used to examine the extent to which reverse mortgage borrowers are able to protect at least half of their housing equity assumes that there is no self-selection into reverse mortgage programs. If elderly home owners who choose to participate in reverse mortgage programs possess personal and property characteristics that are correlated with slower house price growth, then the estimates shown in figure 1 are in fact upper bound estimates, as the probability of home owners being able to protect at least half of their housing equity would actually be lower.

This leads to a need to examine a second issue of importance, that is, self-selection. Reverse mortgage programs in the United States such as the Home Equity Conversion Mortgage (HECM) program have higher loan advance factors than the Australian reverse mortgage programs. These HECM loan advance factors can go up to over $70 \%$ for older age group (see for example Ong, 2008). Hence, using losses data from reverse mortgage programs such as the HECM program, one could empirically test whether the homes of reverse mortgage borrowers appreciate less than the appreciation rates assumed under the reverse mortgage program. However, Australian reverse mortgage loans are not designed to incur losses with maximum loan advance factors going up to around $40 \%$ only, so such empirical analysis would not be possible with Australian program experience data.

Hence, the issue of self-selection is investigated with the assistance of published December 2007 information on Australian reverse mortgage borrowers from the Senior Australians Equity Release Association of Lenders (SEQUAL), a peak industry body that seeks to ensure that lenders who offer equity release products to senior Australians maintain professional standards of practice. The SEQUAL study authored by Hickey et al. (2007) contains information on the age, location, dwelling type and marital status of Australian reverse mortgage borrowers in 2007. This is compared with the general population of elderly home owners in 2007 from the latest wave of the HILDA Survey to gauge the extent of self-selection into reverse mortgage programs in Australia. The 2007 sample from the HILDA Survey is weighted in order to derive population estimates.

Table 5 column 2 below shows the distinguishing characteristics of Australian reverse mortgage borrowers in 2007. The majority of reverse mortgage borrowers resided in New South Wales. 15\% of reverse mortgage loans were secured against apartments while over $80 \%$ were secured against dwellings that were houses. Just under half of reverse mortgage borrowers were partnered and another $40 \%$ were single females. Single males were least likely to participate in reverse mortgage programs. Of particular interest to this study is that the majority of reverse mortgage borrowers in 2007 were aged 75 years or over.

Worryingly, it would appear that elderly home owners aged 75 years or over, an age characteristic associated with slower house price appreciation, are over-represented among reverse mortgage borrowers. Almost half of all reverse mortgage borrowers in 2009 were aged 75 years or over, compared to one-third of the general elderly home owner population. Residents of apartments, which are associated with slower house price appreciation rates, are clearly over-represented among reverse mortgage borrowers. Residents of New South Wales and Victoria, states that are associated with slower house price growth as indicated by the coefficients in table 3, are over-represented among reverse mortgage borrowers while those living in Queensland, where strong house price growth has been observed, is under-represented among. Furthermore, single males and females, who experience slower house price growth than partnered home owners, are over-represented among reverse mortgage borrowers. While over $60 \%$ of the general population of elderly home owners are partnered, a characteristic that is positively correlated with stronger house price growth, only $44 \%$ of reverse mortgage borrowers are in fact partnered. Overall, it is a cause for concern that elderly home owners with characteristics associated with slower house price growth tend to be over- 
represented among reverse mortgage borrowers in Australia, namely, those aged 75 years or over, single, living in apartments or residing in states with relatively slow house price growth.

Table 5: Comparison of reverse mortgage borrowers with elderly home owners in general, 2007, per cent ${ }^{\mathrm{a}}$

\begin{tabular}{|c|c|c|c|}
\hline & & Reverse mortgage borrowers & Elderly home owners \\
\hline \multirow[t]{4}{*}{ Age band: } & Under 65 years & 10 & 28 \\
\hline & $65-69$ years & 19 & 21 \\
\hline & $70-74$ years & 26 & 18 \\
\hline & 75 years or over & 45 & 33 \\
\hline \multirow[t]{2}{*}{ Dwelling type $e^{b}$} & House & 83 & 94 \\
\hline & Flat, unit or apartment & 15 & 6 \\
\hline \multirow[t]{8}{*}{ State: } & New South Wales & 43 & 34 \\
\hline & Victoria & 20 & 18 \\
\hline & Queensland & 19 & 27 \\
\hline & South Australia & 5 & 7 \\
\hline & Western Australia & 9 & 10 \\
\hline & Tasmania & 3 & 2 \\
\hline & Northern Territory & 0 & 2 \\
\hline & Australian Capital Territory & 1 & 2 \\
\hline \multirow[t]{3}{*}{ Marital status: } & Partnered & 44 & 62 \\
\hline & Single males & 16 & 12 \\
\hline & Single females & 40 & 26 \\
\hline
\end{tabular}

Source: Hickey et al. (2008) and author's own estimation from HILDA Survey wave 7

Notes:

a. Estimates from Hickey et al. (2008) are presented with zero decimals. Hence, the HILDA estimates are also presented with zero decimals for consistency's sake.

b. The dwelling type estimates do not add up to $100 \%$ because $2 \%$ of dwelling types were unknown.

It should be noted, however, that between 2007 and 2009, home improvement was one of the top three reasons for participating in reverse mortgage programs cited by Australian reverse mortgage borrowers, the other top two reasons being regular income and debt repayment (Hickey et al., 2007; 2009a; 2009b). Hence, reverse mortgage borrowers may be better able to afford to make home improvements than the general population of elderly homeowners because the reverse mortgage provides access to income with which to pay for property maintenance. This may partially offset the slower house price appreciation rates of elderly home owners should they decide to enter into reverse mortgages.

\section{Conclusion}

For most Australian elderly home owners, their wellbeing is strongly underpinned by their home ownership status, the value of their homes generally representing their most significant asset in old age. The viability of financial instruments such as reverse mortgages where elderly home owners effectively borrow against their housing equity also depend strongly on house prices appreciating enough to offset the outstanding loan balance at the end of the reverse mortgage tenure. The hypothesis that elderly home owners' houses appreciate at below-average rates has been supported by empirical findings in studies from the United States. However, to date no study has examined whether house price appreciation rates among elderly home owners in Australian are systematically lower than those of their younger counterparts.

The results from a random effects model of annual house price appreciation rate presented in this paper shows that old age does have a causal impact on a home owner's house price appreciation rate. After controlling for other influences, being aged 75 years or over lowers annual house price 
appreciation rate by almost 1.4 percentage points; this effect is highly significant at the $1 \%$ level. The average house price appreciation rate in the sample is $7.2 \%$. Hence, the 1.4 percentage point discount represents almost a $20 \%$ discount when expressed as a proportion of the average house price appreciation rate. The median house price in the sample is $\$ 300,000$. Holding all other variables constant, a $7.2 \%$ appreciation rate would indicate that real median house price would have risen by $\$ 21,600$ by the following year. However, the impact of old age of 75 years or over is to result in a real house price growth of only $\$ 17,400$, a discount of $\$ 4,200$ annually.

The home improvement expenditure modelling results indicate that holding other factors constant, being aged 75 years or over reduces annual home improvement expenditure by $\$ 3,130$. This negative old age effect is due to a decline in income as home owners enter old age. It can then be surmised that the impact of reduced home improvement expenditure in old age on house price appreciation rates works largely through the income variable in the house price appreciation rate model. The remaining significant old age effect represented by the age 75 years or over dummy variable may be explained by non-income-related factors. For example, elderly home owners may have tastes in house features that are not typical of newer houses in the neighbourhood. When a house becomes atypical relative to other houses in the market, this can lower demand and increase search costs associated with finding a buyer. Appraisers may then have difficulty finding comparable houses in the neighbourhood (Capozza et al., 2005). As a result, the appraised value of the house may be discounted. Anecdotal evidence suggests that some elderly home owners may be fearful of contracting out home improvement and the disruption this may cause to their homes. A lack of awareness among elderly home owners of the extent to which home improvement expenditures may increase their house prices may be another factor (Davidoff, 2004). These result in under-investment in home improvement, which may contribute to the slower house price appreciation rates experienced by elderly home owners.

The findings of slower house price appreciation during old age raises some issues for the use of reverse mortgage as a retirement funding strategy in Australia, two of which are examined in this paper. Firstly, the majority of Australian elderly home owners wish to protect at least half of their housing equity. The paper's findings indicate that the average likelihood of elderly home owners being able to protect at least half of their housing equity by the end of their loan tenure declines sharply with age, regardless of marital status. Single females aged 75 years or over are least able to sustain a $50 \%$ housing equity protection, with only around $15 \%$ able to do so by the end of their loan tenure. This is a worrying finding because women are disproportionately represented within the older population, comprising two-thirds of those aged over 85 years (Sharp and Austen, 2007). Furthermore, the risks of inadequate retirement income are particularly high for women, due to lower lifetime incomes and superannuation accumulations, and longer life expectancy than men (Jefferson and Preston, 2005). A second worrying finding is that elderly home owners with characteristics associated with slower house price growth appear to be over-represented among reverse mortgage borrowers in Australia, namely, those aged 75 years or over, single, living in apartments or residing in states with relatively slow house price growth.

This paper's findings suggests that elderly home owners who borrow against their housing equity on the basis of average price trends run the risk of being left with little equity to draw on for financial emergencies or bequest purposes. The existing literature generally describes the elderly as less financially sophisticated than the general population, and vulnerable to making poor decisions when considering releasing housing equity due to emotional attachment to the idea of remaining in their homes (ASIC 2005). Hence, many elderly home owners could be basing initial decisions to take out reverse mortgages on overly optimistic market expectations of residual housing equity. 
It should also be noted that this paper's estimates also assume that elderly reverse mortgage borrowers only unlock their housing equity once during the life of their loan tenure whereas the amount of loan taken out could be bigger if a borrower makes additional drawdowns on existing loans. One in every seven reverse mortgage borrowers made such additional drawdowns in Australia in 2009 (Hickey et al. 2009b). Due to the current lack of regulation in the Australian reverse mortgage market, reverse mortgage borrowers may lose their no-negative equity guarantee due to trivial contract breaches and these borrowers will have to bear the outstanding debt themselves in retirement should their loan balance exceed their housing equity (ASIC, 2005; Munro, 2006; Ong, 2008). Governments and the elderly's children are also at risk, as they may have to intervene with additional income support during the elderly's remaining years of old age.

Furthermore, the house price appreciation rates in this paper have been based on a period of strong house prices increases. An extended period of weak housing market conditions such as conditions recently experienced in Australia and other countries, coupled with the fact that the elderly's houses appreciate at below-average rates, could see many elderly reverse mortgage borrowers owing larger amounts on their reverse mortgages than expected. This could become a serious concern in the coming years, given that weak economic conditions have also resulted in a significant decline in the value of their superannuation and investment returns.

This paper's findings indicate that there are complex issues associated with participation in reverse mortgage programs. Hence, the viability of reverse mortgages as a retirement funding strategy is a topic that deserves further in-depth investigation in future research given the vulnerability of the elderly and the increasing trend towards the use of housing wealth to boost retirement funding in an era of rapid population ageing.

\section{Acknowledgements}

The author would like to thank two anonymous referees for their helpful comments and constructive suggestions. The author is also grateful to Anusha Mahendran and Clinton McMurray for their valuable research assistance. This paper uses unit record data from the Household, Income and Labour Dynamics in Australia (HILDA) Survey. The HILDA Project was initiated and is funded by the Australian Government Department of Families, Community Services, Housing and Indigenous Affairs (FaCHSIA) and is managed by the Melbourne Institute of Applied Economic and Social Research (MIAESR). The findings and views reported in this paper, however, are those of the author and should not be attributed to either FaCHSIA or the MIAESR.

\section{References}

Australian Bureau of Statistics (1997). Survey of Income and Housing Costs, Australia: User Guide. Cat. No. 6553,0. Canberra: Australian Bureau of Statistics.

Australian Bureau of Statistics (2001). Australian Standard Geographical Classification. Cat. No. 1216,0. Canberra: Australian Bureau of Statistics.

Australian Bureau of Statistics (2008a). Consumer Price Index, Australia, Time Series Workbook. Cat. No. 6401.0.

Canberra: Australian Bureau of Statistics.

Australian Bureau of Statistics (2008b). Life Tables, Australia, 2005-2007. Cat. No. 3302.0.55.001. Canberra:

Australian Bureau of Statistics. 
Australian Securities and Investments Commission (2005). Equity Release Products. Available:

http://www.asic.gov.au/asic/pdflib.nsf/LookupByFileName/Equity_release_report.pdf/\$file/Equity_release_report.pdf. Accessed 14/08/08.

Australian Securities and Investments Commission (2009). Reverse Mortgages and Other Equity Release Products. Available: http://www.fido.gov.au/equityrelease . Accessed 30/12/09.

Bluestone Equity Release (2008a). Equity Release. http://www.bluestoneequityrelease.com.au/page.aspx?id=55. Accessed 08/08/08.

Bluestone Equity Release (2008b). EQUITYtap Fees and Charges Schedule. Effective 28 April 2008.

http://www.bluestoneequityrelease.com.au/secure/uploadedFiles/pdf/Fees\%20and\%20Charges\%20Schedule\%20\%20BER.pdf?id=0. Accessed 08/08/08.

Bucks, B, \& Penns, K. (2006). Do Homeowners Know Their House Values and Mortgage Terms?, Finance and Economics Discussion Series 2006-3. Washington DC: Federal Reserve Board of Governors.

Capozza, D. R, Israelsen, R. D, \& Thomson, T. A. (2005). Appraisal, agency and atypicality: Evidence from manufactured homes, Real Estate Economics, 33 (3), 509-538.

Commonwealth Bank of Australia (2008). Home Loan Comparison. http://www.commbank.com.au/personal/homeloans/comparison-table.aspx. Accessed 08/08/08.

Davidoff, T. (2004). Maintenance and the Home Equity of the Elderly. Fisher Center for Real Estate and Urban Economics Paper No 03-288. Berkeley, Haas School of Business, University of California.

DiPasquale, D. \& Somerville, C. T. (1995). Do house price indices based on transacting units represent the entire stock? Evidence from the American Housing Survey. Journal of Housing Economics, 4, 195-229.

Goodman, A.C, \& Thibodeau, T.G. (1997). Age-related heteroskedasticity in hedonic house price equations: An extension. Journal of Housing Research 8(2), 299-317.

Goodman, J. L. , \& Ittner, J. B. (1999). The accuracy of home owners' estimates of house value, Journal of Housing Economics, 2(4), 339-57.

Hickey, J., Handley, K., \& Ling, J. (2007). SEQUAL/Trowbridge Deloitte Reverse Mortgage Market Study (December 2007). Sydney: Trowbridge Deloitte.

Hickey, J., Ling, J., \& Cockburn, A. (2009a). SEQUAL/Deloitte Reverse Mortgage Survey (December 2008). http://www.sequal.com.au/content/view/53/78/. Accessed 01/07/09.

Hickey, J., Ling, J., \& Cockburn, A. (2009b). SEQUAL/Deloitte Reverse Mortgage Survey (June 2009). http://www.sequal.com.au/images/sequalpresentation_jun09 230909 final.pdf. Accessed 04/01/10.

House of Representatives Standing Committee on Health and Ageing (2005). Report on a Draft Report of the 40 ${ }^{\text {th }}$ Parliament: Inquiry into Long-Term Strategies to Address the Ageing Of the Australian Population Over the Next 40 Years. Canberra: Commonwealth of Australia.

Jefferson, T. \& Preston, A. (2005). Baby boomers and Australia's other gender wage gap. Feminist Economics, 11(2):79-100.

Kennickell, A. B, \& Starr-McCluer, M. (1997). Retrospective reporting of household wealth: Evidence from the 19831989 Survey of Consumer Finances. Journal of Business and Economic Statistics, 15(4), 452-63.

Kiel, K. A, \& Zabel, J. E. (1999). The accuracy of owner-provided house values: the 1978-1991 American Housing Survey. Real Estate Economics, 27(2), 263-298.

Martin, P. (2009). So can we still feed them now they're 64?. The Age, 30 December. 
MIAESR (Melbourne Institute of Applied Economics and Social Research) (2009). Wave 7 Subject Level Coding Framework: General Release. Melbourne: MIAESR.

Munro, K. (2006). A man's home is his castle. The Sydney Morning Herald, 4 October.

Ong, R. (2004). Ageing in Australia: Financial Independence and Work Disincentive Issues. PhD thesis. Perth: Murdoch University.

Ong, R. (2008). Unlocking housing equity through reverse mortgages: The case of elderly home owners in Australia. European Journal of Housing Policy, 8(1), 61-79.

Quercia, R. G. (1997). House value appreciation among older homeowners: Implications for reverse mortgage programs. Journal of Housing Research, 8(2), 201-223.

Rodda, D.T, \& Patrabansh, S. (2007). Home owner age and house price appreciation. Cityscape: A Journal of Policy Development and Research, 9(3), 123-152.

Senior Australians Equity Release Association of Lenders (SEQUAL) 2008. 'It's on the House' SEQUAL-RFI Reverse Mortgage Study: A Consumer Study into the Attitudes and Perceptions of Australians Age Over 60 Years.

http://www.sequal.com.au/images/stories/sequal_rfi_study.pdf. Accessed 04/01/10.

St. George Bank (2008). Seniors: Live More Comfortably in Retirement by Accessing the Equity in Your Home with a Seniors Access Home Loan. http://www.stgeorge.com.au/loans/home-loans/seniors/default.asp. Accessed 30/09/08.

Sharp, R. \& Austen. S. (2007). The 2006 Federal budget: a gender analysis of the superannuation taxation concessions. Australian Journal of Labour Economics, 10(2), 61-77.

Swan, W. (2009). Budget Speech 2009-10. http://www.budget.gov.au. Accessed 31/07/09.

\section{APPENDIX TABLES}

Table A1: Life expectancy / expected loan tenure, by age and gender, 2007, years

\begin{tabular}{lcc}
\hline Age & Life expectancy / expected loan tenure (years) \\
\cline { 2 - 3 } & Males & Females \\
\hline 60 & 22.6 & 26.0 \\
61 & 21.8 & 25.1 \\
62 & 21.0 & 24.2 \\
63 & 20.1 & 23.4 \\
64 & 19.3 & 22.5 \\
65 & 18.5 & 21.6 \\
66 & 17.8 & 20.8 \\
67 & 17.0 & 19.9 \\
68 & 16.2 & 19.1 \\
69 & 15.5 & 18.3 \\
70 & 14.7 & 17.4 \\
71 & 14.0 & 16.6 \\
72 & 13.3 & 15.8 \\
73 & 12.6 & 15.0 \\
74 & 11.9 & 14.3 \\
75 & 11.3 & 13.5 \\
76 & 10.7 & 12.8 \\
77 & 10.0 & 12.0 \\
78 & 9.4 & 11.3 \\
79 & 8.9 & 10.7 \\
\hline
\end{tabular}




\begin{tabular}{lll}
\hline 80 & 8.3 & 10.0 \\
81 & 7.8 & 9.4 \\
82 & 7.3 & 8.7 \\
83 & 6.8 & 8.2 \\
84 & 6.4 & 7.6 \\
85 & 6.0 & 7.1 \\
86 & 5.6 & 6.6 \\
87 & 5.2 & 6.1 \\
88 & 4.8 & 5.6 \\
89 & 4.5 & 5.2 \\
90 & 4.2 & 4.8 \\
\hline
\end{tabular}

Source: Australian Bureau of Statistics (2008b)

Table A2: Loan advance factor, by age band, 2007, per cent

\begin{tabular}{lc}
\hline Age & Loan advance factor \\
\hline$<65$ years & 14 \\
$65-69$ years & 22 \\
$70-74$ years & 26 \\
$75-79$ years & 33 \\
80 years or over & 40 \\
\hline Source: Hicky et 2 (2007)
\end{tabular}

Source: Hickey et al. (2007) 